\title{
Effectiveness of locally run conservation initiatives in north-east Peru
}

\author{
Noga Shanee, Sam Shanee and Robert H. Hormich
}

\begin{abstract}
Amazonas and San Martin are two of the most densely populated regions in rural Peru and have some of the highest deforestation rates in the country. They are also home to many threatened and endemic species and are considered a high priority for conservation. Under Peruvian law individuals and community groups can create private conservation areas and conservation concessions, and we evaluated the successes and challenges experienced in the creation and management of such areas, using direct observation, questionnaires and key-informant interviews. Our results show that far from being a problem for conservation many rural communities are actively promoting or participating in conservation initiatives on a local scale with landscape-level impacts. These initiatives include land protection, hunting control and reduced deforestation, thus providing effective solutions to threats. The main obstacles we identified in relation to such campesino (peasant farmer) conservation initiatives were the lack of access to support from governmental and nongovernmental institutions and to economic resources to fund the extensive bureaucratic processes of registering protected areas. Many campesino communities bypass these restrictions through informal conservation initiatives.
\end{abstract}

Keywords Campesino, community conservation, landscape conservation, local initiatives, Peru, protected areas

This paper contains supplementary material that can be found online at http://journals.cambridge.org

\section{Introduction}

$\mathrm{P}$ eru has two kinds of non-government protected areas: private conservation areas and conservation concessions. Privately owned land, such as titled family plots or community land, can be registered with the Ministry of the Environment as a private conservation area for an unlimited period and untitled state land can be registered with the relevant regional authorities as a conservation concession for up to 40 years at a time. Ecotourism concessions and

\footnotetext{
Noga Shanee (Corresponding author) and SAm Shanee Neotropical Primate Conservation, 23 Portland Road, Manchester, M32 0PH, UK

E-mail noga@neoprimate.org

Robert H. Horwich Community Conservation, Gays Mills, USA

Received 11 November 2012. Revision requested 4 April 2013.

Accepted 25 June 2013. First published online 1 May 2014.
}

ecological service areas are other legal designations under which land can be protected. Private and communal conservation initiatives are increasingly common in Latin America, especially in the eight Amazonian countries (Bolivia, Brazil, Colombia, Ecuador, Guyana, Peru, Surinam and Venezuela). Of these, Peru has the largest area of privately protected land (Monteferri \& Coll, 2009), with $>1,200,000$ ha in 150 protected areas: 61 private conservation areas, 44 conservation concessions, 40 ecotourism concessions and five ecological service areas (SPDA, 2012). This represents c. $5.4 \%$ of the area covered by the national protected area system (SINANPE) and $0.011 \%$ of the national territory (Conservamos por Naturaleza, 2012; MINAM, 2012).

Although there are some large protected areas in Peru, protected areas in the rural regions of Amazonas and San Martin are generally small and isolated. They are therefore insufficient for species conservation and must be complemented by strategies for landscape-level management (Harris, 1984; Newmark, 1987; Margules \& Pressey, 2000; Ancrenaz et al., 2007). This is especially true for species occurring in populated areas or areas under cultivation, where designated protected areas are infeasible and deforestation levels high (Ranta et al., 1998). Emphasis has been placed on the importance of conserving forest fragments and semi-natural landscapes for species (Harris, 1984; Hansen et al., 1991; Bierregaard Jr et al., 1992; Terborgh, 1992; Bennett, 1999; Gascon et al., 1999). Methodologies include protection and restoration of corridors, in the form of riparian forests or farm boundaries, forest enrichment planting and controlled hunting (Lyon \& Horwich, 1996; Bennett, 1999; Margules \& Pressey, 2000). Lyon \& Horwich (1996) and Horwich et al. (2010) described two case studies from Belize and India in which community-based landscape-level conservation has aided the recovery of threatened primates in anthropogenic landscapes.

The species diversity in the tropical Andean forests of Peru is comparable to that of the country's Amazonian lowlands, which cover c. 20 times more land area (Mittermeier, 1988; Bubb et al., 2004; Pacheco et al., 2009), and the forests have a higher diversity per $\mathrm{km}^{2}$. The regions of Amazonas and San Martin are home to three endemic primate species (Bóveda-Penalba et al., 2009; Shanee, 2011; Shanee et al., 2011), at least three endemic bird species (Schulenberg et al., 2010), 10 Important and Endemic Bird Areas (Stattersfield et al., 1998; O’Dea et al., 2006) and countless endemic plant and invertebrate species (Myers et al., 2000; Rodríguez \& Young, 2000). 
Rural communities in these regions predominantly comprise people of mixed indigenous and European origin. These campesinos, or peasant farmers, endure land insecurity and degraded environmental resources (Loker, 1996; Shanee, 2012a). The majority are migrants who have been displaced from the highlands by the proliferation of mining operations, a scarcity of fertile land, unaffordable land prices and lack of drinking water and fuelwood (Szablowski, 2002; Bury, 2005; Bebbington \& Bury, 2009; Shanee, 2012a). In the 1980 s the construction of the Marginal Highway and the coca Erythroxylum coca boom resulted in mass immigration and associated deforestation in Amazonas and San Martin (Young, 1996; Fjeldså et al., 2005; Shanee, 2012a).

Throughout South America immigrant campesinos are often blamed for environmental destruction. Sundberg (1998) gave many examples of NGO and state discourses blaming campesinos for deforestation and land degradation in Guatemala. Nugent (1993) mentioned that campesino colonists are usually presented in the literature as maladaptive, with a hunger for land and forest resources. They are also blamed for a lack of forest culture and intrinsic antipathy towards naturalistic cultures (Loker, 1996; Nygren, 2000). This reputation is also deeply rooted in the environmental discourse on north-east Peru, which is used by NGOs and public conservation agents to explain the limited success of many conservation initiatives (Shanee, 2012a). However, destructive behaviours towards the environment by campesinos are largely attributable to economic and legal pressures rather than maladaptation or inherent apathy to nature (Trenbath et al., 1990; Loker, 1996; Nygren, 1998). Shanee (2012a) described an amalgam of pressures and state requirements as well as a lack of opportunity for sustainable practices in north-east Peru.

Since the 1980 os there has been a growing understanding that conservation effectiveness depends on partnership with local stakeholders (Western \& Wright, 1994; Brosius et al., 1998; Adams \& Hulme, 2001; Brown, 2002; Adams, 2004). Many conventional conservation interventions promote people-orientated projects, integrating conservation and economic development (Jeanrenaud, 1998; Adams, 2004; Agrawal \& Redford, 2006). Such projects are often criticized for failing to achieve conservation outcomes (Oates, 1999; Terborgh, 1999; Kellert et al., 2000; Wilshusen et al., 2002; Kiss, 2004; Hutton et al., 2005; Durand \& Vázquez, 2010) and sustainable development (Barrett \& Arcese, 1995; Wainwright \& Wehrmeyer, 1998).

Brockington et al. (2008) defined this type of conservation as mainstream conservation. Such schemes are based on neoliberal ideologies whereby nature acquires economic value and is commoditized to pay for itself (Hayden, 2003; Breunig, 2006; Büscher \& Whande, 2007; Sullivan, 2010), suggesting that economic growth and conservation can enhance each other to bring about wholly positive outcomes. Neoliberal conservation discourse identifies local populations as the primary threat to biodiversity because of their proximity to forests (Igoe \& Brockington, 2007). Neoliberal conservation aims to prepare local people to enter the global economy by granting property rights and building capacity to make them competent conservationists. Local environmental knowledge and environmental initiatives are often ignored.

Pathak et al. (2004) defined community conservation as the voluntary conservation of ecosystems, species, ecological services or cultural values by local people through community management decisions and efforts. Local people, through community institutions, are the primary decision-makers and enforce their own regulations, sometimes in collaboration with other stakeholders. Although such locally run conservation projects are increasingly common (Borrini-Feyerabend et al., 2004; Pathak et al., 2004; Horwich et al., 2011) they are seldom described in the literature (Horwich \& Lyon, 2007; Igoe \& Brockington, 2007; Fletcher, 2010; Horwich et al., 2011).

To address this gap we describe our experiences from 5 years of conservation in Amazonas and San Martin, Peru. During this time we encountered hundreds of conservation projects initiated and run by campesinos. These projects varied greatly in magnitude and achievements. Here we analyse, in the context of current conservation trends, the potential of these projects to conserve natural habitats and endemic species in north-east Peru.

\section{Methods}

Our study was carried out in rural Amazonas and San Martin, on the eastern slopes of the Andes in north-east Peru during 2007-2012 (Fig. 1). In 2010 questionnaires (in Spanish) were distributed to 169 randomly chosen adult residents of the community of Yambrasbamba in Amazonas and the villages of La Primavera and Libano in San Martin, to assess local wildlife extraction and deforestation patterns. Questionnaires included socioeconomic questions as well as questions about hunting, forest clearance and attitudes towards forests, wildlife and conservation. We triangulated answers by ethnographic methods, recording and analysing decision-making, conservation actions and people's attitudes and behaviour towards environmental and conservation initiatives. We used ethnographic methodologies, including interviews with key informants from the communities and regional authorities, and participant observations, participating in village meetings and visiting field sites and conservation initiatives (LeCompte \& Schensul, 1999). Through contact with authorities in both regions and with the central government we gathered information about proposed and designated protected areas, the attitudes of the authorities and the challenges they face. We also reviewed 


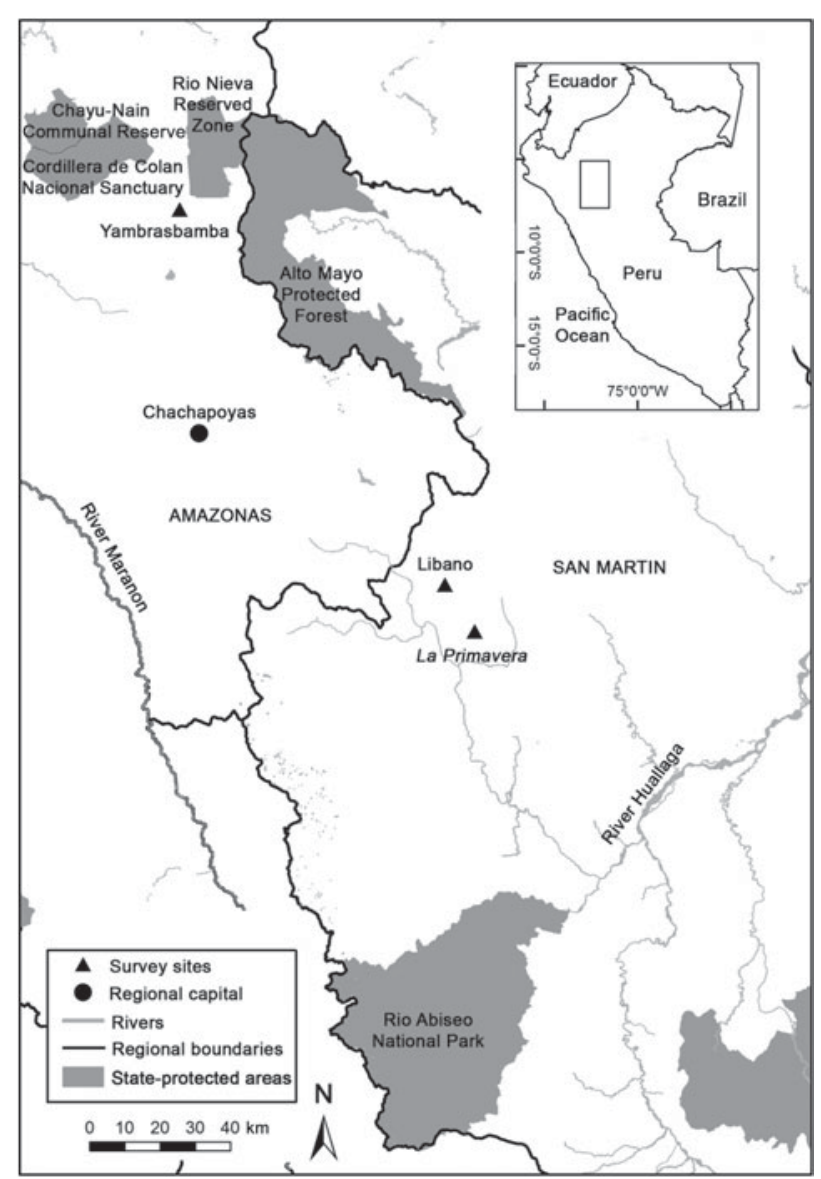

FIG. 1 Location of Amazonas and San Martin, on the eastern slopes of the Andes in north-east Peru, where we carried out our study during 2007-2012. The rectangle on the inset shows the location of the main map in Peru.

relevant national and international laws. We calculated the mean expenditure involved in the creation of protected areas from our own experience and that of other institutions.

Our work involved sustained contact with local groups throughout Amazonas and San Martin, which facilitated a thorough validation of the data as epistemic discourses could be triangulated with the actions they promoted and with their effect in practice. This work took place during our time as directors of the Yellow Tailed Woolly Monkey Project, run by the UK-based NGO Neotropical Primate Conservation.

\section{Results}

\section{Private protected areas}

There are 18 private protected areas in Amazonas and San Martin, with a total of 37,020 ha in Amazonas and 378,407 ha in San Martin. There are 16 proposals for conservation concessions awaiting approval by San Martin's regional government and eight proposals for private conservation areas in Amazonas and San Martin awaiting approval by the Ministry of the Environment. Together these areas cover 97,153 ha (2.5\% of the total land area) in Amazonas and 603,474 ha (11.8\% of the total land area) in San Martin. Twenty-two of these areas are run by campesino communities and associations, six by NGOs, eight by local individuals, four by indigenous communities and associations, and two by local businesses (Supplementary Table $\mathrm{S}_{1}$ ). New proposals are being developed by NGOs and local communities and associations. At least 14 proposals for conservation areas were dropped during the initial stages because of conflicts with development projects or abandoned because of the complex registration process. There are five state-run protected areas in Amazonas, totalling $605,327 \mathrm{ha}$, and four regional and state-run protected areas in San Martin, totalling 997,796 ha.

The majority of interviewees $(74.6 \%)$ were migrants, many from the region of Cajamarca, which they were forced to leave because of the lack of fertile land as a result of overpopulation and mining-related environmental degradation. Most interviewees were small-scale farmers, cultivating a mean of 9.6 ha for subsistence (mainly tubers, corn and beans) and commercial use (cattle, rice, coffee and cacao). According to a focus group in Yambrasbamba the minimum income per family was PEN 450 per month. The estimated maximum income was PEN 5,000 but only two local families earned this amount. Circa $90 \%$ of interviewees were at the lower end of the income scale.

In Yambrasbamba 59\% of people had not been educated beyond primary level; this figure was $74 \%$ in La Primavera and Libano.

Private and communal protected areas in Amazonas and San Martin were found to be initiated by local people who declared part of their lands as intangible zones and later asked private or public conservation agents to assist them in legally registering them as protected areas. Other reserves were initiated by conservation institutions approaching local communities in areas of high conservation priority and encouraging them to create and manage protected areas on or adjacent to their lands.

\section{Challenges of creating and maintaining private protected areas}

The application process for conservation concessions and private protected areas is complicated, expensive and time consuming. It involves regularizing the community's or association's paperwork and, in the case of private protected areas, the land title. The initial proposal must be expanded into a detailed technical document, which is often $>100$ pages, with input from a geographer, biologists of various specialities, a sociologist and a legal advisor and with ongoing communication with the authorities. 
For conservation concessions details of the project must be published in government and national newspapers 1 month before the official application can begin and again after the concession is awarded. The mean cost of these procedures is USD 22,000. After the concession is awarded applicants have 1 year to develop a management plan, build control posts and delimit the area. Conservation initiators are under pressure from the related governmental agencies to maximize their investments, and most local people cannot create their own reserves without the help of NGOs. The full process takes $1.5-5$ years and the land is not legally protected during this time, which sometimes results in conflicts over land use. In such cases the area requires re-delimitation or the initiative may be abandoned.

The majority of conservation organizations who promote private reserves infrequently enter rural areas, resulting in a lack of dissemination of information. Few NGOs support local conservation initiatives in the region and local and national NGOs are constrained by the availability of resources, relying on sporadic and limited funding from larger NGOs (Shanee, 2012a). Consequently many local initiatives, especially smaller ones, are not followed up by any of the NGOs who initially promoted their creation and are never fully realized because of the lack of capacity amongst local initiators to meet the government's requirements.

Socio-political problems in local communities often hinder the creation of reserves, especially in the case of private land protection initiatives within titled community lands, where a two-thirds majority is needed in a general assembly, sometimes requiring the presence of $>1,000$ people, and reserves cannot be created without the full cooperation of community leaders.

Tension and distrust between rural people and the authorities have increased with the introduction of ecotourism and payments for environmental services schemes, especially carbon sequestration through REDD and REDD+ (Reducing Emissions from Deforestation and Forest Degradation) schemes. These schemes are still in the preliminary stages in north-east Peru and it is too early to say whether they will be economically and/or culturally beneficial to rural communities. Many campesinos are led to believe that there is a lot of money to be made from these schemes but the mechanisms are often unclear or even concealed from them. Land-grabbing associated with REDD schemes (Dooley et al., 2011; Espinoza-Llanos \& Feather, 2011; Fairhead et al., 2012) is a growing phenomenon in the lowland areas of Amazonas and San Martin. Such land grabs by NGOs and corporations take three forms: (1) where no land titles exist, large conservation concessions are assigned to these organizations, (2) land is bought from local people who have privately titled lands or only land possession rights, encouraging illegal land invasions, and (3) organizations secure participation in local projects that include communally titled lands. In such cases the benefits of conservation are rarely shared with the local communities.

In San Martin $>1.5$ million ha were designated as permanent production forests for timber extraction as part of a project executed by the National Institute of Natural Resources and financed by WWF. The regional government did not have a procedure for excluding areas requested for conservation from designated forests, even in cases where WWF's maps and the regional land-use plan were contradictory, and therefore an area could be designated as both permanent production forest and as a priority for conservation. This caused an 18-month delay for 10 proposed conservation projects in San Martin. Minor concessions are another barrier to the creation of reserves, and conflicts with extractive industries are one of the main restrictions to both private and state-run protected areas in Amazonas and San Martin.

The proprietor incurs all costs of maintaining reserves, with no funding from the government. They must provide details, in the application and again in the management plan, of how they intend to meet these costs through support from the private sector or forest-related economic activities. The person or entity applying for the concession is expected to demonstrate a thorough understanding of economic processes and accounting for the project to be approved, and many rural people do not have the capacity or resources to do this.

\section{Landscape-level conservation}

In Amazonas and San Martin landscape-level conservation initiatives involve reducing clear-cutting and hunting to reduce fragmentation and to allow wildlife to exist within populated areas. These initiatives are additional to those described above, designating locally run protected areas that are formally registered with the state authorities in areas of moderate to high human population densities. In this case, conservation is administrated within inhabited and agricultural lands without formal separation from other land uses and human activities.

Some communal authorities promote or enforce bans on hunting of threatened species and a general reduction in hunting. The decision to reduce hunting is generally taken in village assemblies. Results of questionnaires and key informant interviews in the five villages of La Esperanza showed that 2 years after bans were introduced hunting was restricted to rodents such as agouti Dasyprocta spp. and mountain paca Cuniculus taczanowskii, which damage crops and have rapid natural reproduction. There were rumours that other species were hunted, but by people living in the remotest areas or by newly arrived migrants. The use of slingshots by children was prohibited, to aid the recovery of bird and arboreal mammal populations in and 
around villages. Bushmeat is rarely an integral part of the diet or economy of rural people in north-east Peru (Shanee, 2012b), and therefore hunting is easier to control than in areas where bushmeat is a more dominant protein source.

Our study revealed that, through communal organizations, local people had started to control and reduce land invasion and immigration to the area. Environmental education coupled with the threat of climate change have catalysed rural communities to reduce forest clearance by more tightly controlling slash-and-burn agriculture and enriching fields and pastures with nitrogen-fixing tree species. This was confirmed in Yambrasbamba and La Primavera, where $63.9 \%$ of people reported that they did not clear-cut additional primary forest but only fallow land and secondary forest. Those that did clear additional primary forests cleared a mean area of 0.9 ha annually. Although clearing and burning of forest did not stop completely it was reduced progressively during the study period. In a meeting in the village of La Primavera in May 2011 residents reported that no one in the village had cleared forest since 2010, only opening areas of regrowth if additional agricultural land was needed. They explained that this was a result of a communal decision and subsequent social pressure. In 2010 the directive board of Yambrasbamba community decided not to assign any more communal lands to new members of the community and obliged people who owned cleared land that they did not work to give it to people who needed it. In other cases villages chose to protect river headwaters to ensure their water supply.

\section{Discussion}

\section{Efficiency of privately owned protected areas}

In Peru private and communal conservation areas supplement the national protected area network. Such initiatives are increasingly popular and engender a sense of pride and inclusion in the local people who implement them (Shanee, 2013). However, many projects proposed by local people are not realized because of a lack of outside support.

As a result of the complicated application process only people with the means and/or networking skills to obtain support from government or NGOs are able to register protected areas. Community leaders are essential to the creation of conservation reserves but their willingness to initiate conservation processes may be influenced by corruption and social pressures (Shanee, 2012a). Until 2010 management plans for private protected areas were required to divide the area into no-use, limited-use and directuse zones but current legislation no longer recognizes no-use zones, which suggests a change in paradigm from conservation as a means of protecting biodiversity to conservation for development. The 2010 legislation and the complex, costly requirements for the creation of reserves essentially exclude people with reduced economic means from being able to initiate protected areas by themselves, and indicate that the government views private conservation initiatives as economic opportunities rather than a means to conserve wildlife. Use of protected areas as incentives for increased economic activity in rural areas and as a means to control and exclude local people has been reported in other countries (Schroeder, 1999; Singh \& van Houtum, 2002; Langholz \& Krug, 2004; Ferguson, 2006; Büscher \& Whande, 2007; Igoe \& Brockington, 2007). Eliminating the option to declare a no-use area also reduces the legal supremacy of private protected areas when conflicts with other land uses arise.

In Peru, and globally, initiatives based on economic incentives are still in the early stages and have yet to be assessed. The implementation of payment for environmental services and REDD projects by local communities may have been hindered by poor planning and dissemination of information (Shanee 2012a, 2013). The assumption that conservation can only be achieved by giving nature a market value presents many theoretical and practical contradictions (Landell-Mills \& Porras, 2002; Rosa et al., 2003; Corbera et al., 2007a,b; Bhusal, 2009; Sullivan, 2009, 2010; MacDonald, 2010; McAfee, 2012). It discourages local people from conserving wildlife for its intrinsic or cultural value and promotes land trafficking and corruption (Corbera et al., 2007a; Fairhead et al., 2012).

We found that for many people in north-east Peru nature conservation is in line with their intrinsic, social, aesthetic and moral values as well as a means to ensure their own future through protection of water sources and mitigation of climate change. In most cases economic benefits were perceived as a welcome but secondary outcome and occasionally even as a hindrance (Shanee, 2013). However, unfulfilled expectations of economic benefits promised by many NGOs and government agents could threaten the future of some private reserves. Many conservation initiatives in Amazonas and San Martin are still in their early stages and thus it is too soon for a full assessment. However, it is likely that the discourse that promotes wholly beneficial conservation solutions with economic gain will collide with low economic outcomes, especially in cases in which poor people are unable to invest in the development of economic alternatives. Together with the effort required to maintain and protect reserves, the unrealistic expectations of the short-term benefits of conservation could dissuade rural communities from initiating conservation initiatives. The promotion of economic benefits could also lead to private protected areas joining Peru's legacy of so-called paper parks (Rodríguez \& Young, 2000; Naughton-Treves et al., 2006), by attracting projects based 
on economic reasoning, which could lead to the abandonment of projects when expectations are unfulfilled.

\section{Efficiency of landscape-level conservation}

Landscape-level conservation initiatives do not separate people from nature by putting nature 'in its place', as described by Adams (2004). They promote environmental stewardship and more harmonious living with surrounding nature (Lyon \& Horwich, 1996; Horwich \& Lyon, 2007). This type of conservation is the least promoted in Amazonas and San Martin. This may be because it is difficult to quantify success or the exact role played by individual institutions. Landscape-level conservation exists informally in these regions but may be less respected by local people and by the initiators themselves because of this informality.

The essence of landscape-level conservation is in its large geographical extension and the inclusion of populated areas. It is mainly informal and therefore has no legal standing against national and regional development plans or against continuous immigration to an area. Moreover, it does not offer complete protection for forests and in most cases will not benefit wildlife that need large areas of undisturbed primary forest, and therefore is generally a complementary activity in combination with the creation of better protected, intangible private and state-run protected areas to efficiently protect a range of species (Margules \& Pressey, 2000). Wildlife can quickly return to non-hunted areas, giving local people a sense of success and pride. This type of conservation also avoids the bureaucratic processes required by the state. Informal conservation initiatives can be implemented on individual, communal or regional levels. They do not require a consensus, bureaucracy or the cooperation of authorities. Horwich et al. (2011) mentioned that in a first meeting with Belizean communities the local authority opposed the idea of a conservation project but the local people were positive about it. The NGO Community Conservation signed individual conservation pledges with each land owner, allowing the gradual accumulation of people rather than the need for a majority vote. Landscapelevel conservation can therefore avoid many of the internal social problems that arise in other conservation projects. It also gives local people a sense of independence, as owners of the project, rather than being reliant on economic and technical assistance from NGOs.

It is difficult to monitor landscape-level conservation, and long-term monitoring of forest and wildlife recovery is required to define its success. However, there are few field biologists working in conservation institutions in Amazonas and San Martin (Shanee, 2012a). A significant, measurable recuperation period is needed for the forest to re-grow and wildlife populations to re-establish. Such long-term projects are infeasible for many NGOs, as they are generally required by funders to provide quick and conclusive results (Büscher \& Dressler, 2007; Igoe \& Croucher, 2007; Büscher, 2008).

\section{Conclusions and recommendations}

Horwich et al. (2010, 2011, 2012) defined the contagion effect, whereby the success and pride of one local group stimulates similar conservation initiatives by other groups. This is a common phenomenon in northern Peru and can explain some of the increase in the number of private reserves. However, because of the complex, expensive process involved many of these areas have not yet been officially designated, especially those managed by local people and communities. NGOs and cooperatives have more resources and power to lobby the authorities. Landscape-level conservation is much more socially equitable and allows for broader participation. Therefore we conclude that the conservation initiatives that yield the most effective solutions are the creation of private protected areas and landscape-level conservation; protected areas give better protection to smaller areas and landscape-level conservation gives partial protection to extensive areas. Although some of these initiatives are relatively small they complement the national protected area network and provide connectivity, and therefore their effect is greater than their combined size.

As mentioned before, local people who create reserves are also responsible for their protection. We recommend basic training in parabiology for local conservationists to facilitate collection of baseline data about the region's flora and fauna (Hesse \& Cuellar, 2007) and increase their sense of ownership and stewardship of protected areas.

Our experience of north-east Peru indicates that an increasing number of rural people are actively proposing conservation projects and investing effort and resources in them. We believe that negative conservation discourses that undermine local initiatives actually damage the ability of local people to get help from NGOs to realize their conservation goals. The success of rural communities in conserving their environments needs to be publicized in both the academic and popular literature, to change national and global discourses. Peru and other high-biodiversity countries should be encouraged to simplify conservation processes to provide equal conservation opportunities for local communities. Landscape-level conservation should be promoted on both local and international levels as a valuable, inexpensive, socially acceptable option for conservation in populated areas.

The effort invested by rural people and the lack of help from NGOs suggest that international conservation organizations tend to increase the scale of their planning and operations to attract funding rather than to focus on local work (Chapin, 2004; Adams \& Hutton, 2007; Brockington 
et al., 2008). We believe that the situation in north-east Peru described here is not unusual and is replicated globally.

\section{Acknowledgements}

We thank Rosa Pineda Yupanqui, Stuart R. Harrop, Marcos Diaz Delgado, Marita Lozano Siguenza, Miguel Alva Reategui, the Peruvian Society for Environmental Law, the Ronda Campesina and the authorities of Amazonas and San Martin for sharing valuable information and knowledge with us. We also thank the NGOs, communities, associations, grassroots organizations and the many other conservation initiators in Amazonas and San Martin for inspiring and participating in this study.

This work was funded by Neotropical Primate Conservation through grants from National Geographic Society, International Primate Protection League, Wild Futures, Primate Society of Great Britain, Apenhuel Primate Conservation Trust, La Vallee des Singes, Primate Conservation Inc., Community Conservation, and the Margot Marsh Biodiversity Foundation.

\section{References}

Adams, W.M. (2004) Against Extinction: The History of Conservation. Earthscan, London, UK.

Adams, W.M. \& Hulme, D. (2001) If community conservation is the answer in Africa, what is the question? Oryx, 35, 193-200.

Adams, W.M. \& Hutton, J. (2007) People, parks and poverty: political ecology and biodiversity conservation. Conservation and Society 5: 147 .

Agrawal, A. \& Redford, K. (2006) Poverty, Development, and Biodiversity Conservation: Shooting in the Dark? Working paper no. 26. Wildlife Conservation Society, New York, USA.

Ancrenaz, M., Dabek, L. \& O'Neil, S. (2007) The costs of exclusion: recognizing a role for local communities in biodiversity conservation. PLoS Biology, 5(11), e289.

Barrett, C.B. \& Arcese, P. (1995) Are integrated conservationdevelopment projects (ICDPs) sustainable? On the conservation of large mammals in sub-Saharan Africa. World Development, 23, 1073-1084.

Bebbington, A.J. \& Bury, J.T. (2009) Institutional challenges for mining and sustainability in Peru. Proceedings of the National Academy of Sciences, 106, 17296.

Bennet T, A.F. (1999) Linkages in the Landscape: the Role of Corridors and Connectivity in Wildlife Conservation. IUCN, Gland, Switzerland, and Cambridge, UK.

Bhusal, Y. (2009) Problems and prospects of REDD in communitybased forest management systems. The Greenery-A Journal of Environment and Biodiversity, 7, 46.

Bierregaard, Jr, R.O., Lovejoy, T.E., Kapos, V., dos Santos, A.A. \& Hutchings, R.W. (1992) The biological dynamics of tropical rainforest fragments. BioScience, 42, 859-866.

Borrini-Feyerabend, G., Pimbert, M., Farvar, J.C.T., Kothari, A. \& Renard, Y. (2004) Sharing Power: Learning by Doing in Co-management of Natural Resources Throughout the World. IIED and IUCN/CEESP/CMWG, Tehran, Iran.
Bóveda-Penalba, A., Vermeer, J., Rodrigo, F. \& Guerra-VÁsquez, F. (2009) Preliminary report on the distribution of Callicebus oenanthe on the eastern feet of the Andes. International Journal of Primatology, 30, 467-480.

BREUNIG, L.A. (2006) Conservation in context: establishing natural protected areas during Mexico's neoliberal reformation. MSc thesis. University of Arizona, Tucson, USA.

Brockington, D., Duffy, R. \& Igoe, J. (2008) Nature Unbound: Conservation, Capitalism and the Future of Protected Areas. Earthscan, London, UK.

Brosius, J.P., Tesing, A.L. \& Zerner, C. (1998) Representing communities: histories and politics of community-based natural resource management. Society and Natural Resources: An International Journal, 11, 157-168.

BROWN, K. (2002) Innovations for conservation and development. The Geographical Journal, 168, 6-17.

Bubb, P., May, I., Miles, L. \& Sayer, J. (2004) Cloud Forest Agenda. UNEP-WCMC, Cambridge, UK.

BURY, J. (2005) Mining mountains: neoliberalism, land tenure, livelihoods, and the new Peruvian mining industry in Cajamarca. Environment and Planning A, 37, 221-239.

BüsCHER, B. (2008) Conservation, neoliberalism, and social science: a critical reflection on the SCB 2007 annual meeting in South Africa. Conservation Biology, 22, 229-231.

BúsCher, B. \& DresSLER, W. (2007) Linking neoprotectionism and environmental governance: on the rapidly increasing tensions between actors in the environment-development nexus. Conservation and Society, 5, 586.

Búscher, B. \& Whande, W. (2007) Whims of the winds of time? Emerging trends in biodiversity conservation and protected area management. Conservation and Society, 5, 22-43.

Chapin, M. (2004) A challenge to conservationists. World Watch, $17,17-31$.

Conservamos por Naturaleza (2012) Conservamos por Naturaleza. Http://www.conservamospornaturaleza.org [accessed 5 November 2012].

Corbera, E., Brown, K. \& Adger, W.N. (2007a) The equity and legitimacy of markets for ecosystem services. Development and Change, 38, 587-613.

Corbera, E., Kosoy, N. \& Martínez Tuna, M. (2007b) Equity implications of marketing ecosystem services in protected areas and rural communities: case studies from Meso-America. Global Environmental Change, 17, 365-380.

Dooley, K., Griffiths, T., Martone, F. \& Ozinga, S. (2011) Smoke and Mirrors: a Critical Assessment of the Forest Carbon Partnership Facility. FERN, Brussels, Belgium, and Forest Peoples Programme, Moreton in Marsh, UK.

Durand, L. \& VÁzquez, L.B. (2010) Biodiversity conservation discourses. A case study on scientists and government authorities in Sierra de Huautla Biosphere Reserve, Mexico. Land Use Policy, 28, 76-82.

Espinoza-Llanos, R. \& Feather, C. (2011) The Reality of REDD+ in Peru: Between Theory and Practice. Indigenous Amazonian Peoples' Analyses and Alternatives. Http://www.forestpeoples.org/ sites/fpp/files/publication/2011/11/reality-redd-peru-betweentheory-and-practice-november-2011.pdf [accessed 10 February 2012].

Fairhead, J., Leach, M. \& Scoones, I. (2012) Green grabbing: a new appropriation of nature? The Journal of Peasant Studies, 39, $237-261$.

Ferguson, J. (2006) Global Shadows: Africa in the Neoliberal World Order. Duke University Press, Durham, USA.

Fjelds ̊, J., Álvarez, M., Lazcano, J. \& León, B. (2005) Illicit crops and armed conflict as constraints on biodiversity conservation in the 
Andes region. AMBIO: A Journal of the Human Environment, 34, 205-211.

Fletcher, R. (2010) Neoliberal environmentality: towards a poststructuralist political ecology of the conservation debate. Conservation and Society, 8, 171.

Gascon, C., Lovejoy, T.E., Bierregatard, Jr, R.O., Malcolm, J.R., Stouffer, P.C., Vasconcelos, H.L. et al. (1999) Matrix habitat and species richness in tropical forest remnants. Biological Conservation, 91, 223-229.

Hansen, A.J., Spies, T.A., Swanson, F.J. \& Ohmann, J. (1991) Conserving biodiversity in managed forests. BioScience, 41, 382-392.

HARrIS, L.D. (1984) The Fragmented Forest: Island Biogeography Theory and the Preservation of Biotic Diversity. University of Chicago Press, Chicago, USA.

Hayden, C. (2003) When Nature Goes Public: The Making and Unmaking of Bioprospecting in Mexico. Princeton University Press, Princeton, USA.

Hesse, A.J. \& Cuellar, S.E. (2007) Manuales Tecnicos, 1er Curso de capacitacion para la formacion de parabiologis. Wildlife Conservation Society, Santa Cruz, Bolivia.

Horwich, R.H., Islari, R., Bose, A., Dey, B., Moshahary, M., DEY, N.K. et al. (2010) Community protection of the Manas Biosphere Reserve in Assam, India, and the Endangered golden langur Trachypithecus geei. Oryx, 44, 252-260.

Horwich, R.H. \& Lyon, J. (2007) Community conservation: practitioners' answer to critics. Oryx, 41, 376-385.

Horwich, R., Lyon, J. \& Bose, A. (2011) What Belize can teach us about grassroots conservation. Solutions, 2.

Horwich, R.H., Lyon, J., Bose, A. \& Jones, C.B. (2012) Preserving biodiversity and ecosystems: catalyzing conservation contagion. In Deforestation Around the World (ed. P. Moutinho), pp. 283-318. InTech, Rijeka, Croatia.

Hutton, J., Adams, W.M. \& Murombedzi, J.C. (2005) Back to the barriers? Changing narratives in biodiversity conservation. Forum for Development Studies, 32, 341-370.

igoe, J. \& Brockington, D. (2007) Neoliberal conservation: a brief introduction. Conservation and Society, 5, 432.

Igoe, J. \& Croucher, B. (2007) Conservation, commerce, and communities: the story of community-based wildlife management areas in Tanzania's northern tourist circuit. Conservation and Society, 5, 534 .

JeAnRenaud, S. (1998) Can the leopard change its spots? Exploring people-oriented conservation in WWF. PhD thesis. University of East Anglia, Norwich, UK.

Kellert, S.R., Mehta, J.N., Ebbin, S.A. \& Lichtenfeld, L.L. (2000) Community natural resource management: promise, rhetoric, and reality. Society and Natural Resources, 13, 705-715.

KIss, A. (2004) Making biodiversity conservation a land-use priority. In Getting Biodiversity Projects to Work (eds T.O. McShane \& M.P. Wells), pp. 98-123. Columbia University Press, New York, USA.

Landell-Mills, N. \& Porras, I.T. (2002) Silver Bullet or Fools' Gold? A Global Review of Markets for Forest Environmental Services and their Impact on the Poor. International Institute for Environment and Development, London, UK.

LANGHOLZ, J. \& KRUG, W. (2004) New forms of biodiversity governance: non-state actors and the Private Protected Area Action Plan. Journal of International Wildlife Law \& Policy, 7, 9-29.

LeCompte, M.D. \& Schensul, J.J. (1999) Designing and Conducting Ethnographic Research. AltaMira Press, London, UK.

LOKer, W.M. (1996) 'Campesinos' and the crisis of modernization in Latin America. Journal of Political Ecology, 3, 69.
Lyon, J. \& Horwich, R.H. (1996) Modification of tropical forest patches for wildlife protection and community conservation in Belize. In Forest Patches in Tropical Landscapes (eds J. Shelhas \& R. Greenberg), pp. 205-230. Island Press, Washington, DC, USA.

MacDonald, K.I. (2010) The devil is in the (bio)diversity: private sector 'engagement' and the restructuring of biodiversity conservation. Antipode, 42, 513-550.

Margules, C.R. \& Pressey, R.L. (2000) Systematic conservation planning. Nature, 405, 243-253.

McAfee, K. (2012) The contradictory logic of global ecosystem services markets. Development and Change, 43, 105-131.

MINAM (2012) Areas de Conservacion Privada. Ministerio del Ambiente, Lima, Peru. Http://www.minam.gob.pe [accessed 5 December 2012].

Mittermeier, R.A. (1988) Primate diversity and the tropical rainforest. In Biodiversity (ed. E.O. Wilson), pp. 145-154. National Academy Press, Washington, DC, USA.

Monteferri, B. \& Coll, D. (eds) (2009) Conservación privada y comunitaria en los países amazónicos. Sociedad Peruana de Derecho Ambiental, Lima, Peru.

Myers, N., Mittermeier, R.A., Mittermeier, C.G., DA Fonseca, G.A.B. \& Kent, J. (2000) Biodiversity hotspots for conservation priorities. Nature, 403, 853-858.

Naughton-Treves, L., Alvarez-Berros, N., Brandon, K., Bruner, A., Holland, M.B., Ponce, C. et al. (2006) Expanding protected areas and incorporating human resource use: a study of 15 forest parks in Ecuador and Peru. Sustainability: Science, Practice \& Policy, 2, 32-44.

NeWmark, W.D. (1987) A land-bridge island perspective on mammalian extinctions in western North American parks. Nature, 325, 430-432.

Nugent, S. (1993) Amazonian Caboclo Society: An Essay on Invisibility and Peasant Economy. Berg, Oxford, UK.

Nygren, A. (1998) Environment as discourse: searching for sustainable development in Costa Rica. Environmental Values, 7 , 201-222.

Nygren, A. (2000) Development discourses and peasant-forest relations: natural resource utilization as social process. Development and Change, 31, 11-34.

OAtes, J.F. (1999) Myth and Reality in the Rain Forest: How Conservation Strategies Are Failing in West Africa. University of California Press, London, UK.

O’Dea, N., Araújo, M.B. \& Whittaker, R.J. (2006) How well do Important Bird Areas represent species and minimize conservation conflict in the tropical Andes? Diversity and Distributions, 12, 205-214.

Pacheco, V., Cadenillas, R., Salas, E., Tello, C. \& Zeballos, H. (2009) Diversity and endemism of Peruvian mammals. Revista Peruana de Biologia, 16, 5-32.

Pathak, N., Bhatt, S., Balasinorwala, T., Kothari, A. \& Borrini-Feyerabend, G. (2004) Community Conserved Areas: A Bold Frontier for Conservation. Http://greenwonderland.co.uk/ upload/document/guidelines-communityconservedareas.pdf [accessed 10 October 2013].

Ranta, P., Blom, T., Niemela, J., Joensuu, E. \& Siitonen, M. (1998) The fragmented Atlantic rain forest of Brazil: size, shape and distribution of forest fragments. Biodiversity and Conservation, 7 , $385-403$.

Rodríguez, L.O. \& Young, K.R. (2000) Biological diversity of Peru: determining priority areas for conservation. AMBIO: A Journal of the Human Environment, 29, 329-337.

Rosa, H., Kandel, S. \& Dimas, L. (2003) Compensation for Environmental Services and Rural Communities. Lessons from the 
Americas and Key Issues for Strengthening Community Strategies. Political Economy Research Institute, Amherst, USA.

Schroeder, R.A. (1999) Geographies of environmental intervention in Africa. Progress in Human Geography, 23, 359.

Schulenberg, T.S., Stotz, D.F., Lane, D.E., O’Neill, J.P. \& Parker, T.A. (2010) Birds of Peru. Princeton University Press, Princeton, USA.

SHANEE, N. (2012a) The dynamics of threats and conservation efforts for the Tropical Andes hotspot in Amazonas and San Martin, Peru. PhD thesis. University of Kent, Canterbury, UK.

ShaneE, N. (2012b) Trends in local wildlife hunting, trade and control in the Tropical Andes Biodiversity Hotspot, northeastern Peru. Endangered Species Research, 19, 177-186.

Shanee, N. (2013) Campesino justification for self-initiated conservation actions: a challenge to mainstream conservation. Journal of Political Ecology, 20, 413-428.

ShaneE, S. (2011) Distribution survey and threat assessment of the yellow-tailed woolly monkey (Oreonax flavicauda; Humboldt 1812), northeastern Peru. International Journal of Primatology, 32, $691-707$.

Shanee, S., Tello-Alvarado, J.C., Vermeer, J. \& Boveda-Penalba, A.J. (2011) GIS risk assessment and GAP analysis for the Andean titi monkey (Callicebus oenanthe). Primate Conservation, 26, 17-23.

Singh, J. \& van Houtum, H. (2002) Post-colonial nature conservation in southern Africa: same emperors, new clothes? GeoJournal, 58, 253-263.

SPda (Sociedad Peruana de Derecho Ambiental) (2012) Iniciativa para la Conservación Privada y Comunal. Http://www. conservacionprivada.org/ [accessed 10 August 2012].

Stattersfield, A., Crosby, M., Long, A. \& Wege, D. (1998) Endemic Bird Areas of the World: Priorities for Biodiversity Conservation. BirdLife International, Cambridge, UK.

Sullivan, S. (2009) Green capitalism, and the cultural poverty of constructing nature as service provider. Radical Anthropology, 3 , $18-27$.

SulLivan, S. (2010) 'Ecosystem service commodities'-a new imperial ecology? Implications for animist immanent ecologies, with Deleuze and Guattari. New Formations, 69, 111-128.

SundberG, J. (1998) NGO landscapes in the Maya Biosphere Reserve, Guatemala. Geographical Review, 88, 388-412.
Szablowski, D. (2002) Mining, displacement and the World Bank: a case analysis of Compania Minera Antamina's operations in Peru. Journal of Business Ethics, 39, 247-273.

Terborgh, J. (1992) Maintenance of diversity in tropical forests. Biotropica, 24, 283-292.

Terborgh, J. (1999) Requiem for Nature. Island Press/Shearwater Books, Washington, DC, USA.

Trenbath, R.B., Conway, G.R. \& Craig, I.A. (1990) Threats to sustainability in intensive agricultural systems: analysis and implications for management. In Agroecology: Researching the Ecological Basis for Sustainable Agriculture (ed. S. Gliessman), pp. 337-365. Pergamon Press, New York, USA.

Wainwright, C. \& Wehrmeyer, W. (1998) Success in integrating conservation and development? A study from Zambia. World Development, 26, 933-944.

Western, D. \& Wright, R.M. (1994) Natural Connections: Perspectives in Community-based Conservation. Island Press, Washington, DC, USA.

Wilshusen, P.R., Brechin, S.R., Fortwangler, C.L. \& West, P.C. (2002) Reinventing a square wheel: critique of a resurgent 'protection paradigm' in international biodiversity conservation. Society \& Natural Resources, 15, 17-40.

YounG, K.R. (1996) Threats to biological diversity caused by coca/ cocaine deforestation in Peru. Environmental Conservation, 23, 7-15.

\section{Biographical sketches}

Noga Shanee is a cofounder of Neotropical Primate Conservation and a co-director of the Yellow Tailed Woolly Monkey Project. Her main research interests are political ecology of biodiversity loss and conservation initiatives, illegal wildlife trafficking, and connections between cultures, religions and the environment. SAM SHANEE is a cofounder of Neotropical Primate Conservation and a co-director of the Yellow Tailed Woolly Monkey Project. His work focuses on the conservation of attitudinally restricted species and populations and their interactions with anthropogenic and natural environments. Rов HORWICH has researched the behaviour and ecology of birds and mammals for 50 years, with a focus on infant development, including methods for translocating primates and reintroducing cranes. A community conservationist since 1984 , he has developed flexible methods for motivating communities to protect forests and wildlife. 